\title{
TECHNOLOGICAL AND SENSORY QUALITY OF GRAIN AND BAKING PRODUCTS FROM SPELT WHEAT
}

\author{
Marketa Kyptova, Petr Konvalina, Tran Dang Khoa \\ University of South Bohemia in Ceske Budejovice, Czech Republic \\ kyptova.marketa@seznam.cz
}

\begin{abstract}
This work deals with the baking quality of the spelt wheat grain (Triticum spelta L.) compared with bread wheat (Triticum aestivum L.). Mixed flours were made of different share of spelt wheat and bread wheat (in total 11 mixtures) in 2016 in the Česke Budejovice in the laboratories of the Faculty of Agriculture. The technological quality of these mixtures was analyzed, focusing on standard evaluation methods (protein content, characteristic of gluten or swellability of protein). The analysis was supplemented by complete rheological analysis made by Mixolab II. Bread was used as a model product. Subsequently, sensory evaluation of baked bread from the previously prepared mixtures was done. Part of the analysis was to estimate the economic basic bread recipe with different proportions of bread wheat and spelt wheat. The results were statistically analyzed via STATISTICA 9.1 (StatSoft, Inc., USA). It was proved that the flour made of spelt can give cereal products with a higher nutritional value. The results have shown that the spelt grain is much more suitable for baking. Its advantage is the higher protein content and higher resistance of kneading of the dough and starch gelatinization rate, which was statistically confirmed. The main disadvantage is the higher price of spelt. According to the results, the ideal utilization of spelt wheat based on sensory analysis and economic calculations seems to be the mixture of spelt wheat and bread wheat, which results in an undeniable decrease of the product cost, and hence effects the common customer choice and taste preferences.
\end{abstract}

Key words: spelt wheat; bread wheat; technological quality; baking test; sensory evaluation.

\section{Introduction}

Cereals are the most widespread of all the crops. They are grown worldwide. Wheat is ranked among four most significant crops from the human caloric intake point of view (Moudry et al., 2013a; Moudry et al., 2013b; Jelinkova et al., 2016). Apart from their nutritional, health and technological parameters, impact of cereals of the environmental sustainability was also evaluated in our research, pursuant to our attempt to evaluate farming and food products from broader point of view (Dalgaard et al., 2006). Food consumption patterns were counted and assessed in particular (Wallgren \& Hojer, 2009). As far as alternative wheat cultivars are concerned, spelt wheat is the most widespread alternative wheat species in the organic farming; spelt wheat growing areas have been extending (Korczyk - Szabo \& Lacko Bartosova, 2013; Konvalina et al., 2014). In 2014, spelt wheat was grown on the area of 2,000 ha and the average yield amounted to $2.11 \mathrm{t} \mathrm{ha}^{-1}$ in the Czech Republic (Hrabalova, 2015). In Austria, for instance, the growing area is larger than in the Czech Republic nowadays; spelt wheat is grown on the area of almost 10,000 ha there. Any statistics mapping spelt wheat growing areas worldwide do not exist. However, spelt wheat is supposed to be grown on the area of hundreds of thousands of hectares in total. A wide range of products are made from spelt wheat grains - bakery products, various semi-products, pasta or coffee (Konvalina et al., 2011; Stehno et al., 2010).

Spelt wheat is often said to contain more nutrients in its grains. Its grains are supposed to be more easily digestible than bread wheat ones. There is not, nevertheless, any unequivocal evidence for that claim.
High grain protein content $(13-20 \%)$ has already been described in details. Compared to bread wheat, spelt wheat contains much more proteins. Spelt wheat composition of amino acids is very similar to bread wheat one, if related to the same grain protein content (Ranhotra et al., 1995). In spite of high grain protein content, spelt wheat grain is suitable for malt and beer production (Krieger, 2004). Grela, Baranowska \& Krusinski (1993) noticed some differences in E-vitamin content between spelt wheat and bread wheat. Compared to bread wheat grains, spelt wheat grains contain more zinc (Ranhotra et al., 1995). Cubadda and Marconi (1996) described a high baking quality of spelt wheat in their study, despite spelt wheat gluten being less tough or firm and provoking worse rheological properties of dough than bread wheat one (Schmitz, 2006). Therefore, it is highly advisable to use a mixture of spelt wheat and bread wheat flour for the production of bakery products. Considering that spelt wheat is sold at a higher price than bread wheat, such a mixture of flours allows us to produce bakery products at lower prices. Gluten stability and rheological properties of dough have improved thanks to hybridizing spelt and bread wheat cultivars. Such species are not, nevertheless, accepted by consumers in Austria or Switzerland. They are highly sensitive to wheat gluten. Some grains might even contain more carotenoids that cause darker colour of spelt wheat bakery products, compared to bread wheat ones (Grausgruber et al., 2004; Schmitz, 2006). The Italian research showed (Marconi et al., 2002) that pasta could be made from spelt wheat grains containing more proteins (Lacko-Bartosova \& LackoBartosova, 2016). In order to make good-quality 
pasta, temperature has to be increased when pasta is being dried. A study showed (Ruibal-Mendieta et al., 2005) that wholegrain spelt wheat flour was richer in fats than bread wheat one, and unsaturated fatty acids in particular. High ash, copper, iron, zinc, magnesium or phosphorus contents were detected in some spelt wheat samples (and in the aleuronic layer of caryopsis in particular). On the other hand, there was $40 \%$ less leaf acid in spelt wheat than in bread wheat. Digestible fibre content was also lower in hulled wheat grains than in naked wheat ones (Grausgruber et al., 2004).

This article aims at evaluating primary parameters of the milling and baking quality. Such evaluation is accompanied with a complex rheological evaluation (carried out with Mixolab II) and sensory analysis as well. Optimizing technological and economic parameters of the mixtures of spelt and bread wheat is another partial objective.

\section{Materials and Methods}

Wheat samples: The samples were purchased from a commercial shop, products were from Bioharmonie bio baking flour. The study was done in 2016 in the Ceske Budejovice in the laboratories of the Faculty of Agriculture. Evaluation of parameters of the milling and baking quality: Standardized methods were used to determine Gluten index, falling number (ICC 107/1), wet gluten content (ICC 137/1), Zeleny test (ICC 116/1) and moisture (ČSN ISO 712). The nitrogen content was determined according to the Kjeldahl method (ICC 105/2); we used conversion factors, known as $\mathrm{N}$ factors, 5.70 for all flours. Advanced evaluation of the baking quality was made by rheological system Mixolab II (ICC 173). Sensory analysis and economic cost analysis: The breadmaking test was done using the standard procedure: $300 \mathrm{mLwater}, 500 \mathrm{~g}$ flour, $16 \mathrm{~g}$ salt, $16 \mathrm{~g}$ sugar, $3 \mathrm{~g}$ cumin and $3 \mathrm{~g}$ dried yeast in the home breadmaker Moulinex Home Bread Inox on the $4 \mathrm{~h}$ program. The sensory analysis of various bread types was performed (those types of bread differed in the spelt wheat share). Twenty-five participants participated in the evaluation of 5 different breads. They were asked to fill in a questionnaire which included the following questions: taste, smell, visual aspects of bread crust and bread crumb, touch and hearing impressions. Statistical data analysis: The data were statistically analysed (at level $\mathrm{p}<0.05$ ) by analysis of variance to determine significant differences among samples using program STATISTICA 9.1 (StatSoft, Inc., USA).

\section{Results and Discussion}

Evaluation of primary parameters of the milling and baking quality

Table 1 shows the summary of all baking quality parameters that were monitored and evaluated in our research. Measured values corresponded to long-time figures. High falling number values were measured for both wheat species; they indicated a minor damage to grain starch as a consequence of pre-harvest lodging. We measured very high values of falling number; they exceeded the limit and were several times higher. Such high values could have a negative effect on volume and sensory properties of bakery products and bread crumb (Every et al., 2002). Gluten index (GI) indicates the stability and flexibility of gluten. Higher values of GI are better for mechanical dough processing. Bread wheat or stronger bread wheat mixtures attained higher values than spelt wheat or any stronger spelt wheat mixture in our research. There was a statistically significant difference between spelt and bread wheat values. On the other hand, there was a minimum difference in Zeleny test values between spelt and bread wheat. Spelt and bread wheat were similar in protein swelling capacity; pursuant to Tukey HSD test, it was a statistically significant trend.

Wet gluten content is closely linked to grain protein content (Famera et al., 2015). Spelt wheat usually attains higher values of grain protein content than bread wheat. It is similar to cereal mixtures. $100 \%$ pure spelt flour contained higher amount of proteins in our research. It is a general trend nowadays - spelt wheat grains contain more nutritionally valuable proteins than bread wheat ones, in the organic farming in particular. There was a statistically significant difference between $100 \%$ bread wheat sample and spelt wheat one in our research; however, there were statistically non-significant differences in every single mixture and they mingled. Dvoracek \& Curn (2003) described the following trend - there are more protoplasmic protein fractions, and nutritionally valuable albumins and globulins in particular, in spelt wheat grains. Bread wheat grains usually contain more spectra of prolamins which have a positive effect on their technological quality - e. g. they attain higher values of Gluten Index (see Table 1). On the other hand, these are proteinous fractions that might cause wheat to be toxic to people suffering from celiac disease (Petr et al., 2003).

\section{Advanced evaluation of the baking quality - rheological properties of dough}

We analysed it with Mixolab II that allowed us to assess the complex rheology of dough during the baking process (Papouskova et al., 2011). In fact, we studied and evaluated the stability of dough an ability and capacity of dough to rise and to keep leavening gas or a product of rising activity (produced by yeast cells activity) - carbon dioxide. The analysis carried out with Mixolab II also involved an evaluation of starch quality (Kahraman et al., 2008). The impact of starch on the baking quality was detected and 


\section{Basic parameters of baking quality (average of two repetitions)}

\begin{tabular}{|c|c|c|c|c|c|c|c|}
\hline Sample & Spelt wheat (\%) & $\begin{array}{c}\text { Bread wheat } \\
(\%)\end{array}$ & $\begin{array}{c}\text { Falling } \\
\text { number }(\mathrm{s})\end{array}$ & GI & Wet gluten & $\begin{array}{c}\text { Zeleny test } \\
(\mathrm{mL})\end{array}$ & $\begin{array}{c}\text { Protein } \\
\text { content (\%) }\end{array}$ \\
\hline 1 & 100 & 0 & $585^{\mathrm{h}}$ & $52.3^{\mathrm{a}}$ & $43.8^{\mathrm{k}}$ & $11.0^{\mathrm{a}}$ & $14.84^{\mathrm{e}}$ \\
\hline 2 & 90 & 10 & $528^{\mathrm{ac}}$ & $58.1^{\mathrm{b}}$ & $42.2^{\mathrm{j}}$ & $11.5^{\mathrm{ab}}$ & $14.78^{\mathrm{e}}$ \\
\hline 3 & 80 & 20 & $516^{\mathrm{b}}$ & $59.8^{\mathrm{c}}$ & $41.8^{\mathrm{i}}$ & $11.5^{\mathrm{ab}}$ & $14.59^{\mathrm{de}}$ \\
\hline 4 & 70 & 30 & $537^{\mathrm{d}}$ & $60.0^{\mathrm{d}}$ & $40.5^{\mathrm{h}}$ & $11.0^{\mathrm{a}}$ & $14.41^{\mathrm{de}}$ \\
\hline 5 & 60 & 40 & $533^{\mathrm{cd}}$ & $60.9^{\mathrm{e}}$ & $39.8^{\mathrm{g}}$ & $12.0^{\mathrm{bcd}}$ & $14.07^{\mathrm{ce}}$ \\
\hline 6 & 50 & 50 & $562^{\mathrm{g}}$ & $66.6^{\mathrm{f}}$ & $37.3^{\mathrm{f}}$ & $11.0^{\mathrm{a}}$ & $13.77^{\mathrm{bc}}$ \\
\hline 7 & 40 & 60 & $527^{\mathrm{a}}$ & $68.0^{\mathrm{h}}$ & $36.7^{\mathrm{e}}$ & $11.8^{\mathrm{bc}}$ & $13.53^{\mathrm{abc}}$ \\
\hline 8 & 30 & 70 & $506^{\mathrm{f}}$ & $69.7^{\mathrm{i}}$ & $36.1^{\mathrm{d}}$ & $12.3^{\mathrm{cd}}$ & $13.28^{\mathrm{ab}}$ \\
\hline 9 & 20 & 80 & $471^{\mathrm{e}}$ & $67.4^{\mathrm{g}}$ & $33.7^{\mathrm{b}}$ & $12.3^{\text {cd }}$ & $13.20^{\mathrm{ab}}$ \\
\hline 10 & 10 & 90 & $524^{\mathrm{a}}$ & $70.0^{\mathrm{j}}$ & $35.3^{\mathrm{c}}$ & $12.5^{\mathrm{d}}$ & $12.95^{\mathrm{a}}$ \\
\hline 11 & 0 & 100 & $514^{\mathrm{b}}$ & $72.4^{\mathrm{k}}$ & $33.1^{\mathrm{a}}$ & $12.0^{\mathrm{bcd}}$ & $12.55^{\mathrm{a}}$ \\
\hline
\end{tabular}

Note: Values marked with the same letter did not show statistically significant differences at a significance level of $\mathrm{p}<0.05$ (Tukey HSD test).

evaluated in our research. We mostly detected and evaluated starch gelatinization and degradation, which meant a stability of hot gel (Mixolab applications handbook, 2008).

As the detailed figures in Diagram 1 and Table 2, Table 3 show, spelt wheat flour is more stable, and spelt wheat dough leavens longer. It is also obvious that high values of $\mathrm{C} 1$ are kept if a spelt wheat share decreases to $50 \%$. A positive effect of top-quality spelt wheat persists. From the Amplitude point of view (the Amplitude reflects and expresses the flexibility of dough), there are not any significant differences. It has been $95 \%$ confirmed by the statistics as well. Lower value of the $50 \%$ mixture was provoked by a measurement deviation in our research.

The most stable dough was made from 100\% spelt wheat flour in our research. Such trend showed that spelt wheat dough needed to be worked and processed intensively. Less stable dough was made from a mixture of spelt wheat and bread wheat; the stability of mixed dough reduced considerably. Such dough should be worked and processed with care and did not need to be kneaded too much. However, Kohajdova \& Karovicova (2007) showed the contrary trend. Therefore, we will have to deal with this aspect more in the future. Rheological properties of dough deteriorated (in all $\mathrm{C} 2-\mathrm{C} 5$ parameters) if bread wheat share increased in a flour mixture in our research. Proportion of proteins decreased and they got weaker. Starch got less gelatinized and it was less stable. Retrogradation values were also lower. From the sensory point of view, spelt wheat bread should be more attractive to consumers (spelt wheat attains higher values of all the parameters we have been measuring); it stays fresh longer and it does not crumble. We detected very small differences as both kinds of flour were quite good-quality in our research. There were also small differences from the statistical point of view.

As far as $\alpha$ direction (C1-C2) was concerned, minimum differences in protein weakening speed (when proteins are heated, they weaken) were noticed in our research. Such result showed that the baking technology and temperature should be similar to spelt wheat. There was a noticeable difference in starch gelatinization speed ( $\beta$ direction, C3-C4) between spelt wheat and bread wheat. Spelt wheat starch got gelatinized later (more slowly) than bread wheat one. Therefore, spelt wheat dough requires longer time of baking and lower temperature in general. Enzymatic degradation speed of spelt wheat is lower, as $\gamma$ direction (C5-C4) shows (see Diagram 1).

Correlations shown in Table 4 demonstrate a relation between parameters. $\mathrm{C} 1$ parameter and amplitude had a statistically non-significant correlation in our research. No statistically significant correlation emerged between these parameters and the other ones. Zeleny test and protein content had an interesting negative correlation. A negative correlation also existed between gluten index and protein content. Both negative correlations were statistically significant $(99.9 \%)$. Such a negative correlation confirmed that spelt wheat contained more proteins and attained lower values of Zeleny test and gluten index. Schober, Clarke \& Kuhn (2002) state that spelt wheat dough has got worse rheological properties than bread wheat one. They also noticed that rheological properties of dough improved if the share 
of spelt wheat decreased in flour mixture. Stiegert and Blanc (2000) confirmed that protein weakening had a negative effect on dough and it made it less stable. Generally said, we have come to the same conclusions as the above-mentioned authors. We, nevertheless, recorded the contrary trend in the dough stability in our research. Spelt bread leavened less, and it had got lower bread volume - which complied with Kohajdova \& Karovicova (2007). Bread volume is not the only and deciding factor; sensory properties of bread are also important. Therefore, the sensory analysis was made.
Sensory analysis and economic cost analysis

Results of the sensory analysis showed that pure bread wheat was found the best of all types of bread in our research (it got 2.22 points on average). It is not so difficult to interpret it - bread wheat bread resembles those sold in shops and supermarkets. Mixed bread wheat/spelt wheat bread (there is $30 \%$ of spelt wheat in it) was found the second best one (it got 2.44 points in the sensory analysis). It is also available in shops and supermarkets. Mixed bread wheat/spelt wheat bread (there is $70 \%$ of spelt wheat in it) was found the third best one (it got 2.49 points in the test). The last two mixtures were very similar to each other in

Table 2

Detailed results of the analyzes on Mixolabu II (parameters dough rheology)

\begin{tabular}{|c|c|c|c|c|c|c|}
\hline \multirow{2}{*}{ Sample } & \multirow{2}{*}{$\begin{array}{l}\text { Spelt wheat } \\
(\%)\end{array}$} & \multirow{2}{*}{$\begin{array}{c}\text { Bread wheat } \\
(\%)\end{array}$} & $\mathrm{C} 1$ & Amplitude & Stability & $\mathrm{C} 2$ \\
\hline & & & $\min$ & $\mathrm{Nm}$ & $\min$ & $\mathrm{Nm}$ \\
\hline 1 & 100 & 0 & $2.72^{\mathrm{a}}$ & $0.07^{\mathrm{a}}$ & $6.99^{d}$ & $0.40^{\mathrm{b}}$ \\
\hline 2 & 90 & 10 & $2.71^{\mathrm{a}}$ & $0.06^{\mathrm{a}}$ & $5.59^{\mathrm{c}}$ & $0.39^{\mathrm{ab}}$ \\
\hline 3 & 80 & 20 & $2.81^{\mathrm{a}}$ & $0.06^{\mathrm{a}}$ & $5.07^{\mathrm{bc}}$ & $0.37^{\mathrm{ab}}$ \\
\hline 4 & 70 & 30 & $2.60^{\mathrm{a}}$ & $0.06^{\mathrm{a}}$ & $4.79^{\mathrm{abc}}$ & $0.36^{\mathrm{ab}}$ \\
\hline 5 & 60 & 40 & $2.89^{\mathrm{a}}$ & $0.05^{\mathrm{a}}$ & $4.61^{\mathrm{abc}}$ & $0.37^{\mathrm{ab}}$ \\
\hline 6 & 50 & 50 & $2.84^{\mathrm{a}}$ & $0.05^{\mathrm{a}}$ & $4.20^{\mathrm{ab}}$ & $0.38^{\mathrm{ab}}$ \\
\hline 7 & 40 & 60 & $2.85^{\mathrm{a}}$ & $0.08^{\mathrm{a}}$ & $4.54^{\mathrm{abc}}$ & $0.36^{\mathrm{ab}}$ \\
\hline 8 & 30 & 70 & $2.94^{\mathrm{a}}$ & $0.06^{\mathrm{a}}$ & $4.39^{\mathrm{ab}}$ & $0.37^{\mathrm{ab}}$ \\
\hline 9 & 20 & 80 & $2.85^{\mathrm{a}}$ & $0.065^{\mathrm{a}}$ & $3.87^{\mathrm{a}}$ & $0.38^{\mathrm{ab}}$ \\
\hline 10 & 10 & 90 & $2.58^{\mathrm{a}}$ & $0.065^{\mathrm{a}}$ & $3.90^{\mathrm{a}}$ & $0.35^{\mathrm{a}}$ \\
\hline 11 & 0 & 100 & $3.07^{\mathrm{a}}$ & $0.055^{\mathrm{a}}$ & $4.05^{\mathrm{ab}}$ & $0.37^{\mathrm{ab}}$ \\
\hline
\end{tabular}

Note: Note: Values marked with the same letter did not show statistically significant differences at a significance level of $\mathrm{p}<0.05$ (Tukey HSD test). $\mathrm{C} 1=$ Dough hydratation and mixing, $\mathrm{C} 2=$ The protein weaking.

Table 3

Detailed results of the analyzes on Mixolabu II (parameters dough rheology)

\begin{tabular}{|c|c|c|c|c|c|c|}
\hline \multirow{2}{*}{ Sample } & $\mathrm{C} 3$ & $\mathrm{C} 4$ & $\mathrm{C} 5$ & $\alpha$ & $\beta$ & $\gamma$ \\
\cline { 2 - 7 } & $\mathrm{Nm}$ & $\mathrm{Nm}$ & $\mathrm{Nm}$ & $\mathrm{Nm}$ & $\mathrm{Nm}$ & $\mathrm{Nm}$ \\
\hline 1 & $1.660^{\mathrm{a}}$ & $1.523^{\mathrm{a}}$ & $2.471^{\mathrm{ab}}$ & $-0.076^{\mathrm{ab}}$ & $0.652^{\mathrm{b}}$ & $0.001^{\mathrm{bc}}$ \\
\hline 2 & $1.633^{\mathrm{a}}$ & $1.501^{\mathrm{a}}$ & $2.4355^{\mathrm{ab}}$ & $-0.087^{\mathrm{a}}$ & $0.538^{\mathrm{ab}}$ & $-0.005^{\mathrm{abc}}$ \\
\hline 3 & $1.628^{\mathrm{a}}$ & $1.518^{\mathrm{a}}$ & $2.5025^{\mathrm{b}}$ & $-0.081^{\mathrm{ab}}$ & $0.267^{\mathrm{a}}$ & $-0.01^{\mathrm{abc}}$ \\
\hline 4 & $1.5635^{\mathrm{a}}$ & $1.4595^{\mathrm{a}}$ & $2.3375^{\mathrm{abc}}$ & $-0.09^{\mathrm{a}}$ & $0.431^{\mathrm{ab}}$ & $-0.012^{\mathrm{abc}}$ \\
\hline 5 & $1.5985^{\mathrm{a}}$ & $1.494^{\mathrm{a}}$ & $2.358^{\mathrm{abc}}$ & $-0.073^{\mathrm{ab}}$ & $0.411^{\mathrm{ab}}$ & $0.016^{\mathrm{c}}$ \\
\hline 6 & $1.597^{\mathrm{a}}$ & $1.492^{\mathrm{a}}$ & $2.355^{\mathrm{abc}}$ & $-0.069^{\mathrm{ab}}$ & $0.344^{\mathrm{ab}}$ & $-0.013^{\mathrm{abc}}$ \\
\hline 7 & $1.571^{\mathrm{a}}$ & $1.441^{\mathrm{a}}$ & $2.274^{\mathrm{abc}}$ & $-0.072^{\mathrm{ab}}$ & $0.405^{\mathrm{ab}}$ & $-0.027^{\mathrm{ab}}$ \\
\hline 8 & $1.56^{\mathrm{a}}$ & $1.457^{\mathrm{a}}$ & $2.316^{\mathrm{abc}}$ & $-0.069^{\mathrm{ab}}$ & $0.31^{\mathrm{ab}}$ & $-0.005^{\mathrm{abc}}$ \\
\hline 9 & $1.587^{\mathrm{a}}$ & $1.477^{\mathrm{a}}$ & $2.3135^{\mathrm{abc}}$ & $-0.049^{\mathrm{b}}$ & $0.295^{\mathrm{ab}}$ & $-0.024^{\mathrm{abc}}$ \\
\hline 10 & $1.554^{\mathrm{a}}$ & $1.4365^{\mathrm{a}}$ & $2.231^{\mathrm{ac}}$ & $-0.065^{\mathrm{ab}}$ & $0.317^{\mathrm{ab}}$ & $-0.04^{\mathrm{a}}$ \\
\hline 11 & $1.5585^{\mathrm{a}}$ & $1.427^{\mathrm{a}}$ & $2.1585^{\mathrm{c}}$ & $-0.069^{\mathrm{ab}}$ & $0.3^{\mathrm{ab}}$ & $-0.024^{\mathrm{a}}$ \\
\hline
\end{tabular}

Note: Values marked with the same letter did not show statistically significant differences at a significance level of $\mathrm{p}<0.05$ (Tukey HSD test). $\mathrm{C} 3=$ Starch gelatization, $\mathrm{C} 4=$ Starch breakdown, $\mathrm{C} 5=$ Starch retrogradation, $\alpha=$ protein weakening speed under heating effect, $\beta=$ speed of starch gelatinization, $\gamma=$ speed of enzyme degradation. 


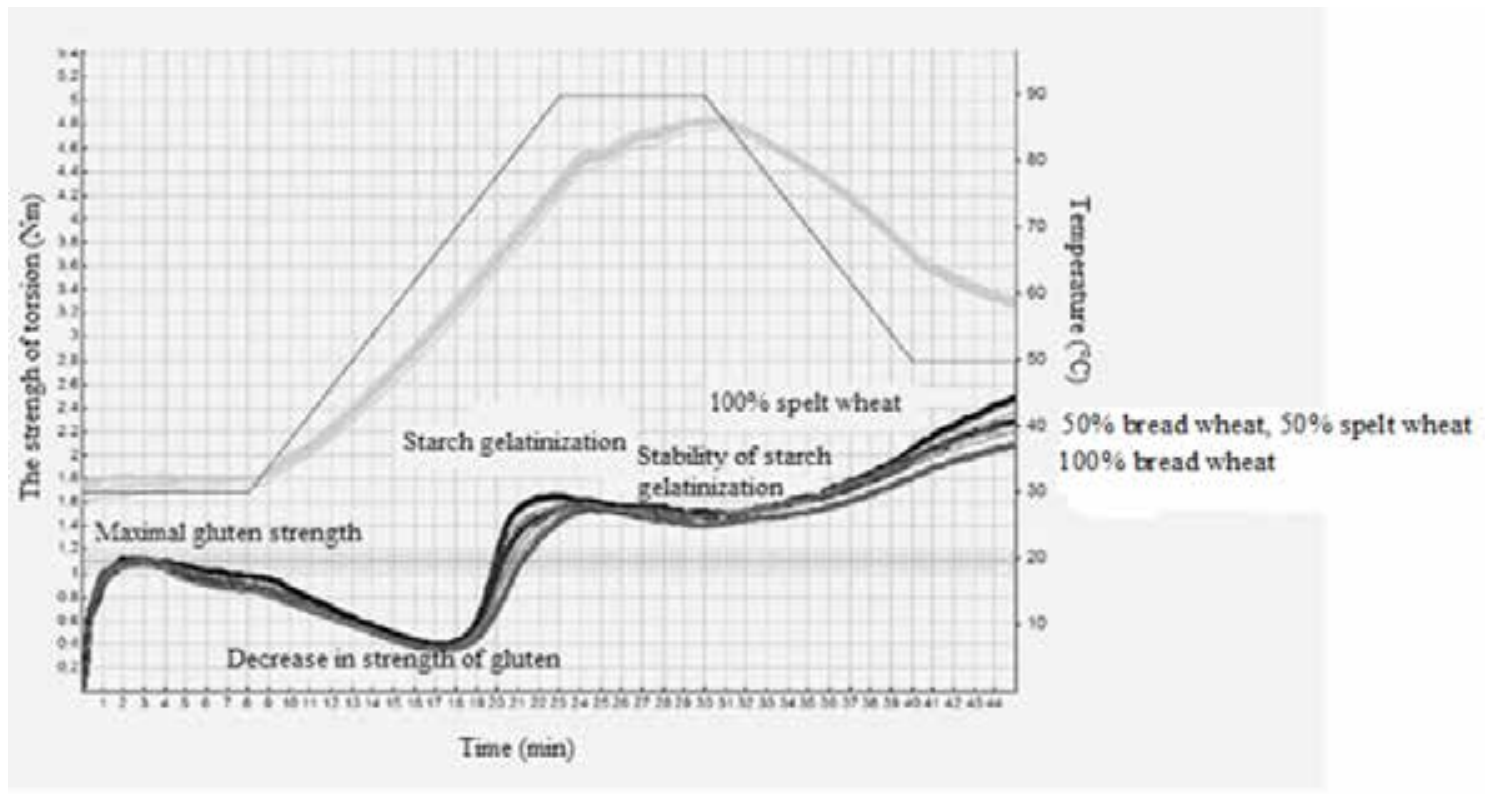

Figure 1. Comparison of the 11 mixtures with different proportions of spelled flour and flour of bread wheat.

\section{Results of correlation analys}

\begin{tabular}{|c|c|c|c|c|c|c|c|c|c|c|c|}
\hline & Mean \pm SD & $\mathrm{S}$ & $\mathrm{C} 2$ & $\mathrm{C} 3$ & $\mathrm{C} 5$ & $\alpha$ & $\beta$ & PC & FN & GI & WG \\
\hline S & $4.73 \pm 0.91$ & 1 & & & & & & & & & \\
\hline C2 & $0.37 \pm 0.01$ & $0.57^{* *}$ & 1 & & & & & & & & \\
\hline C3 & $1.59 \pm 0.04$ & $0.62^{* *}$ & $0.85^{* * *}$ & 1 & & & & & & & \\
\hline C4 & $1.48 \pm 0.04$ & $0.43^{*}$ & $0.81^{* * *}$ & $0.91^{* * *}$ & & & & & & & \\
\hline C5 & $2.34 \pm 0.11$ & $0.63^{* *}$ & $0.68^{* * *}$ & $0.81^{* * *}$ & 1 & & & & & & \\
\hline$\alpha$ & $-0.07 \pm 0.01$ & $-0.48^{*}$ & $-0.09^{\text {ns }}$ & $-0.22^{\text {ns }}$ & $-0.28^{\text {ns }}$ & 1 & & & & & \\
\hline$\beta$ & $0.39 \pm 0.13$ & $0.74^{* * *}$ & $0.33^{\text {ns }}$ & $0.24^{\text {ns }}$ & $0.26^{\text {ns }}$ & $-0.35^{\text {ns }}$ & 1 & & & & \\
\hline$\gamma$ & $-0.01 \pm 0.02$ & $0.47^{*}$ & $0.45^{*}$ & $0.47^{*}$ & $0.59^{* *}$ & $-0.34^{\text {ns }}$ & $0.34^{\text {ns }}$ & & & & \\
\hline PC & $13.81 \pm 0.77$ & $0.78^{* * *}$ & $0.56^{* *}$ & $0.71^{* * *}$ & $0.84^{* * *}$ & $-0.62^{* *}$ & $0.56^{* *}$ & 1 & & & \\
\hline FN & $527 \pm 28$ & $0.65^{* *}$ & $0.42^{\text {ns }}$ & $0.41^{\text {ns }}$ & $0.35^{\text {ns }}$ & $-0.43^{*}$ & $0.59^{* *}$ & $0.53^{*}$ & 1 & & \\
\hline GI & $64 \pm 6$ & $-0.87^{* * *}$ & $-0.58^{* *}$ & $-0.69^{* * *}$ & $-0.76^{* * *}$ & $0.53^{*}$ & $-0.69^{* * *}$ & $-0.94^{* * *}$ & $-0.59^{* *}$ & 1 & \\
\hline WG & $38 \pm 4$ & $0.84^{* * *}$ & $0.5^{*}$ & $0.66^{* * *}$ & $079^{* * *}$ & $-0.65^{* * *}$ & $0.62^{* *}$ & $0.97^{* * *}$ & $0.62^{* *}$ & $-0.95^{* * *}$ & 1 \\
\hline ZT & $11.70 \pm 0.55$ & $0.56^{* *}$ & $-0.52^{*}$ & $-0.45^{*}$ & $-0.46^{*}$ & $0.56^{* *}$ & $-0.47^{*}$ & $-0.66^{* * *}$ & $-0.7^{* * *}$ & $0.66^{* * *}$ & $-0.66^{* * *}$ \\
\hline
\end{tabular}

Note: $\mathrm{S}=$ Stability, $\mathrm{C} 1=$ Dough hydratation and mixing, $\mathrm{C} 2=$ The protein weaking, $\mathrm{C} 3=$ Starch gelatization, $\mathrm{C} 4=\mathrm{Starch}$ breakdown, $\mathrm{C} 5=$ Starch retrogradation, $\alpha=$ protein weakening speed under heating effect, $\beta=$ speed of starch gelatinization, $\gamma=$ speed of enzyme degradation, $\mathrm{PC}=$ protein content, $\mathrm{FN}=$ falling number, $\mathrm{GI}=$ gluten index, $\mathrm{WG}=$ wet gluten content, $\mathrm{ZT}=$ Zelny test.

the analysis. Pure spelt wheat bread got 2.61 points and was found worse in general. It is understandable as it is not widely spread or available in shops or supermarkets. Consumers are not used to it. According to the results of the sensory analysis, bread made from a mixture of bread wheat and spelt wheat is supposed to be the best and is highly recommended. It is more attractive to consumers and is sold for a reasonable price. Results of the sensory analysis are shown in Table 5. It confirmed the finding a lot of authors had revealed - bread made from a mixture of spelt wheat flour and any other kind of flour was supposed to be the best (Kohajdová \& Karovičová, 2007).

Cost analysis - bread made from a flour mixture, various spelt wheat shares

Spelt wheat is mostly bought by consumers who use it in order to bake home-made bread. Nowadays, there is a lack of flour on the market. It leads to an important consequence $-\mathrm{a}$ high price of spelt wheat 
The results of sensory evaluation of bread prepared from various mixtures

\begin{tabular}{|c|l|c|}
\hline Order & \multicolumn{1}{|c|}{ Mixture } & \multicolumn{1}{|c|}{ Point evaluation } \\
\hline 1 & Bread wheat $(100 \%)$ & 2.22 \\
\hline 2 & $70 \%$ bread wheat, 30\% spelt wheat & 2.44 \\
\hline 3 & $30 \%$ bread wheat, $70 \%$ spelt wheat & 2.49 \\
\hline 4 & $50 \%$ bread wheat, $50 \%$ spelt wheat & 2.59 \\
\hline 5 & Spelt wheat $(100 \%)$ & 2.61 \\
\hline
\end{tabular}

Table 6

Assessment of the costs of bread baked from a mixture of different proportions of spelt and bread wheat

\begin{tabular}{|c|c|c|}
\hline Proportion of spelt wheat (\%) & Proportion of bread wheat (\%) & Price for 0.75 kg of bread (EUR) \\
\hline 100 & 0 & 1.74 \\
\hline 90 & 10 & 1.67 \\
\hline 80 & 20 & 1.56 \\
\hline 70 & 30 & 1.48 \\
\hline 60 & 40 & 1.37 \\
\hline 50 & 50 & 1.30 \\
\hline 40 & 60 & 1.22 \\
\hline 30 & 70 & 1.11 \\
\hline 20 & 80 & 1.04 \\
\hline 10 & 90 & 0.93 \\
\hline 0 & 100 & 0.78 \\
\hline
\end{tabular}

flour. A simple economic cost analysis was made: costs of home-made bread were calculated. Bread wheat flour's price was 1.35 EUR per $\mathrm{kg}^{-1}$, whereas spelt wheat flour's price was 3.13 EUR per $\mathrm{kg}^{-1}$. Other ingredients cost 0.18 EUR per one baking cycle.

As Table 6 shows, pure (100\%) spelt wheat bread costs 1.74 EUR, whereas pure $(100 \%)$ bread wheat bread costs 0.78 EUR. Pure spelt wheat bread is twice as expensive. Its price is not accepted by a lot of consumers. Therefore, it is better to bake bread from a mixture of spelt wheat e.g. (50\% of spelt wheat). The price of one baking cycle drops to 1.30 EUR.

\section{Conclusions}

Cereal products made from spelt wheat have got a higher added value. Bread was used as a model product in our research. The results of our research showed that spelt wheat grains were suitable for baking (from the technological point of view). It was confirmed by usual baking quality methods and a complex rheological analysis carried out with Mixolab II. Spelt wheat is also more suitable, as its grains have got much higher nutritional value than bread wheat grains. Results of the sensory analysis and economic cost analysis showed that spelt wheat should be mixed with bread wheat and used for baking. This is the optimal solution for spelt wheat. If we use such a mixture, we come to a provable baking cost reduction and the sensory properties of such bakery products are closer to consumer preferences of taste.

\section{Acknowledgements}

This work was supported by the research project No. NAZV QJ1310072 of the National Agency for Agricultural Research of the Ministry of Agriculture of the Czech Republic and the University of South Bohemia in České Budějovice (project No. GAJU 094/2016/Z). I would like to thank to Dr. Martin Šlachta for help with statistical data analysis.

\section{References}

1. Cubadda, R., \& Marconi, E. (1996). Technological and nutritional aspects in emmer and spelt. In: Padulosi, S., Hammer, K., Heller, J. (Eds.), Hulled wheat, Proc. $1^{\text {st }}$ Int. Workshop on hulled wheat, 21 - 22 July 1995 , Castelvecchio Pascoli, Italy, pp. 203 - 211. IPGI, Rome, Italy. 
2. Dalgaard, R., Halberg, N., Kristensen, I.S., \& Larsen, I. (2006). Modelling representative and coherent Danish farm types based on farm accountancy data for use in environmental assessments. Agriculture, Ecosystems \& Environment, 117(4), 223 - 237.

3. Dvoracek, V., \& Curn, V. (2003). Evaluation of protein fractions as biochemical markers for identification of spelt wheat cultivars (Triticum spelta L.). Plant Soil Environ, 49, 99 - 105.

4. Every, D., Simmons, L., Al-Hakkak, J., Hawkins, S., \& Ross, M. (2002). Amylase, falling number, polysaccharide, protein and ash relationships in wheat millstreams. Euphytica, 126(1), 135 - 142. DOI: 10.1023/A:1019699000975.

5. Famera, O., Mayerova, M., Buresova, I., Kourimska, L., \& Prasilova, M. (2015). Influence of selected factors on the content and properties of starch in the grain of non-food wheat. Plant, Soil and Environment.

6. Grausgruber, H., Scheiblauer, J., Schonlechner, R., Ruckenbauer, P., \& Berghofer, E. (2004). Variability in chemical composition and biologically active constituents of cereals. Eds. J. Vollmann, H. Grausgruber, \& P. Ruckenbauer (pp. 23 - 26). Genetic Variation for Plant Breeding.

7. Grela, E., Baranowska, M., \& Krusinski, R. (1993). Tocopherol contents of legumes and cereals. Przemysl Spozywczy, 47(11), $311-312$.

8. Hrabalova, A. Ed. (2015). Rocenka Ekologické zemedelstvi v Ceske republice. (Yearbook of Organic farming in the Czech Republic) Mze. Praha, 72 s. (in Czech).

9. Jelinkova, Z., Moudry, J., Bernas, J., Kopecky, M., \& Konvalina, P. (2016). Environmental and economic aspects of Triticum aestivum L. and Avena sativa growing. Open Life Sciences, 11(1), 533 - 541. DOI: 10.1515/biol-2016-0069.

10. Kahraman, K., Sakıyan, O., Ozturk, S., Koksel, H., Sumnu, G., \& Dubat, A. (2008). Utilization of Mixolab ${ }^{\circledR}$ to predict the suitability of flours in terms of cake quality. European Food Research and Technology, 227(2), 565 - 570. DOI: 10.1007/s00217-007-0757-y.

11. Kohajdova, Z., \& Karovicova, J. (2007). Effect of incorporation of spelt flour on the dough properties and wheat bread quality. Żywność Nauka Technologia Jakość, 14(4).

12. Konvalina, P., Capouchova, I., Stehno, Z., Moudry jr, J., \& Moudry, J. (2011). Fusarium identification by PCR and DON content in grain of ancient wheat. Journal of Food, Agriculture \& Environment, 9(3\&4), $321-325$.

13. Konvalina, P., Moudry, J. srov., Suchy, K., Capouchova, I., Janovska, D. (2014). Diversity of carbon isotope discrimination in genetic resources of wheat. Cereal Research Communications. 42(4). 687 - 699.

14. Korczyk - Szabo, J., Lacko - Bartošová, M. (2013). Crum texture of spelt bread. Journal of Central European Agriculture, 14(4), 1343 - 1352.

15. Korber-Grohne, U. (1989). The history of spelt (Triticum spelta) on the basis of archaeobotanical findings from Neolithic to Medieval times, and the data by written sources until today. Dire, Treignes.

16. Krieger, M. (2004). Bierspezialitaten aus Dinkel, Emmer und Einkorn. Schrift (Beer specialities from Dinkel, Emmer and Einkorn). Genetics Resources 23, 176 - 181. (in German).

17. Lacko-Bartosova, M., Lacko-Bartosova, L. (2016). Effect of farming system on colour components of wheat doodles. Potravinarstvo, 10(1), $413-417$.

18. Marconi, E., Carcea, M., Schivone, M., \& Cubadda, R. (2002). Spelt (Triticum spelta L.) pasta quality: Combined effect of flour properties and drying conditions. Cereal Chemistry, 79(5), 634.

19. Mixolab applications handbook. (2008). Rheological and enzymatic analysis. Chopin Applications Laboratory.

20. Moudry, J., Jelinkova, Z., Jaresová, M., Plch, R., Moudry, J., \& Konvalina, P. (2013a). Assessing greenhouse gas emissions from potato production and processing in the Czech Republic. Outlook on Agriculture, 42(3), 179 - 183.

21. Moudry, J., Jelinkova, Z., Plch, R., Moudry, J., Konvalina, P., \& Hyspler, R. (2013b). The emissions of greenhouse gases produced during growing and processing of wheat products in the Czech Republic. Journal of Food Agriculture \& Environment, 11(1), 1133 - 1136.

22. Papouskova, L., Capouchova, I., Kostelanska, M., Skerikova, A., Prokinova, E., Hajslova, J., \& Famera, O. (2011). Changes in baking quality of winter wheat with different intensity of Fusarium spp. contamination detected by means of new rheological system. Czech Journal of Food Sciences, 29(4), 420 - 429.

23. Petr, J., Michalik, I., Tlaskalova, H., Capouchova, I., Famera, O., Urminska, D., \& Knoblochova, H. (2003). Extention of the spectra of plant products for the diet in coeliac disease. Czech journal of food sciences, 21(2), $59-70$.

24. Ranhotra, G., Gelroth, J., Glaser, B., \& Lorenz, K. (1995). Baking and Nutritional Qualities of a Spelt Wheat Sample. Food Sci. Technol.-Lebensm.-Wiss. Technol. 28, 118 - 122. 
25. Ruibal-Mendieta, N.L., Delacroix, D.L., Mignolet, E., Pycke, J.M., Marques, C., Rozenberg, R., \& Delzenne, N.M. (2005). Spelt (Triticum aestivum ssp. spelta) as a source of breadmaking flours and bran naturally enriched in oleic acid and minerals but not phytic acid. Journal of agricultural and food chemistry, 53(7), 2751 - 2759. DOI: 10.1021/jf048506e.

26. Schmitz, K. (2006). Dinkel ein Getreide mit Zukunft für die Bäckerei. (Spelled a grain with future for the bakery) Getreidetechnologie, 59(1), 48 - 51. (in German).

27. Schober, T.J., Clarke, C.I., \& Kuhn, M. (2002). Characterization of functional prperties of gluten proteins in spelt cultivars using rheological and quality factor measurements. Cereal Chemistry, 79(3), 408.

28. Stehno, Z., Bradova, J., Dotlacil, L., \& Konvalina, P. (2010). Landraces and obsolete cultivars of minor wheat species in the Czech collection of wheat genetic resources. Czech Journal of Genetics and Plant Breeding, 46 (Special Issue).

29. Stiegert, K., \& Blanc J.P. (2000). Japanese demand for wheat protein quantity and quality. Journal Agric. Res. Econ. 22, $104-119$.

30. Wallgren, C., \& Hojer, M. (2009). Eating energy- identifying possibilities for reduced energy use in the future food supply system. Energy Policy, 37(12), 5803 - 5813. 